\title{
NDT EXAMINATION HASIL PENGELASAN SMAW DENGAN VARIASI MEREK ELEKTRODA E6013
}

\author{
Syaripuddin, Ferry Budhi Susetyo dan Tias Hamzah \\ Jurusan Teknik Mesin, Fakultas Teknik, Universitas Negeri Jakarta
}

\begin{abstract}
ABSTRAK
Penelitian ini bertujuan untuk mengetahui karakteristik unsur fluk dari ketiga elektroda dengan uji komposisi, mengetahui karakteristik unsur kawat inti beberapa ketiga elektroda dengan uji komposisi, mengetahui cacat las yang terjadi dari hasil pengelasan menggunakan ketiga elektroda dengan pengujian penetrant. Penelitian ini menggunakan beberapa pengujian yaitu dengan uji komposisi untuk mengetahui karakteristik unsur, kawat inti dan fluks beberapa elektroda, uji penetrant untuk mengetahui ada tidaknya cacat las yang terjadi. Karakteristik unsur fluks berbeda dari ketiga elektroda, karakteristik unsur kawat inti berbeda dari ketiga elektroda, cacat las yang terjadi berdasarkan hasil uji visual dari hasil pengelasan menggunakan elektroda A adalah undercutting dan fault of electrode change, untuk hasil pengelasan menggunakan elektroda B adalah undercutting, untuk hasil pengelasan menggunakan elektroda $C$ tidak terlihat adanya cacat las. cacat las yang terjadi berdasarkan hasil uji penetrant dari hasil pengelasan menggunakan elektroda A adalah undercutting dan fault of electrode change, untuk hasil pengelasan menggunakan elektroda B adalah undercutting, untuk hasil pengelasan menggunakan elektroda $C$ adalah weld spatter.
\end{abstract}

Kata kunci : SMAW, E 6013, cacat las, uji komposisi

\section{PENDAHULUAN}

Las elektroda terbungkus adalah cara pengelasan yang banyak digunakan pada masa ini. Dalam cara pengelasan ini digunakan kawat elektroda logam yang dibungkus dengan fluks [Harsono Wiryosumarto,1996]. Berbagai macam jenis elektroda baik dalam negeri maupun luar memenuhi kebutuhan pasar.

Penelitian ini dilakukan untuk mengetahui karakteristik hasil pengelasan SMAW dengan mengunakan elektroda jenis E6013 berdiamter 3,2 mm merk A, B dan $\mathrm{C}$ yang ada dipasaran pada baja karbon rendah. Pengujian yang dilakukan diantaranya dengan uji penetrnt dan uji komposisi. Uji penetrant dilakukan untuk mengetahui adanya tidaknya cacat las yang terjadi dari hasil pengelasan. Uji komposisi untuk mengetahui karakteristik unsur dari fluks dan kawat inti dari elektroda merk A, B dan C.

\section{TEORI DASAR}

\section{A. Pengelasan SMAW}

Menurut Sri Widharto dalam bukunya "Petunjuk Kerja Las" adalah suatu cara untuk menyambung benda padat dengan jalan mencairkan melalui pemanasan.[Sri Widharto, 1987]
Penjelasan tentang pengelasan lainnya menurut Hery Sonawan dan Rochim Suratman dalam

bukunya "Pengantar Untuk Memahami Proses Pengelasan Logam" Pengelasan adalah salah satu teknik penyambungan logam dengan cara mencairkan sebagian logam induk dan logam pengisi dengan atau tanpa logam tambahan dan menghasilkan sambungan yang kontinu. [Hery Sonawan, 2006]

Dari beberapa definisi diatas, pengelasan dapat diartikan proses penyambungan logam dengan bahan tambahan atau tanpa bahan tambahan dengan cara memberikan perlakuan panas untuk mencairkan logam induk atau logam pengisi sehingga terbentuk ikatan.

Shelded metal arc welding (SMAW) adalah las busur nyala listrik, adalah pengelasan dengan mempergunakan busur nyala listrik sebagai sumber panas pencair logam. Jenis las ini yang paling lazim dipakai di mana-mana untuk hampir semua keperluan pengelasan. 


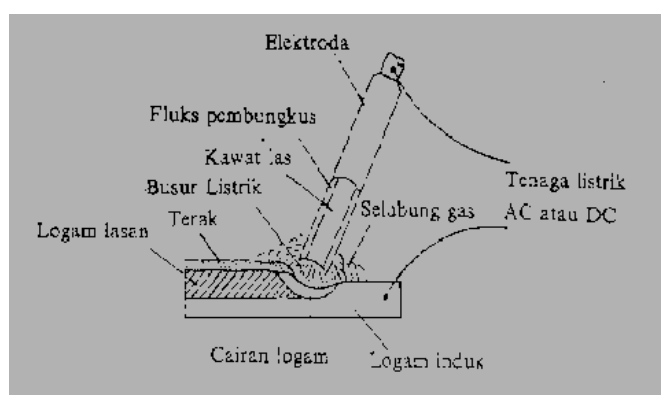

Gambar 1. Las Busur dengan Elektroda

Terbungkus [Harsono Wiryosumarto,1996]

\section{B. Elektroda Las}

Di dalam las elektroda terbungkus fluks memegang peran penting karena fluks dapat bertindak sebagai (1) Pemantap busur dan penyebab kelancaran pemindahan butir-butir cairan logam; (2) Sumber terak atau gas yang dapat melindungi logam cair terhadap udara disekitarnya; (3) Pengaturan penggunaan; (4) Sumber unsur-unsur paduan.

Fluks biasanya terdiri dari bahan-bahan tertentu dengan perbandingan yang tertentu pula. Bahanbahan yang digunakan dapat digolongkan dalam bahan pemantapan busur, pembuatan terak, penghasil gas, deoksidator, unsur paduan dan bahan pengikat. [Harsono Wiryosumarto,1996]

Standarisasi elektroda, baik JIS maupun dalam ASTM didasarkan pada jenis fluks, posisi pengelasan dan arus las. Walaupun dalm pemberian simbol agak berbeda antara kedua sistem tersebut, tetapi pada dasarnya adalah sama. Sebagai contoh misalnya huruf D dalam JIS dan E dalam ASTM, keduanya berarti elektroda yang dimaksud adalah elektroda terbungkus. Dua angka yang pertama baik dalam $J I S$ satuannya adalah $\left(\mathrm{kg} / \mathrm{mm}^{2}\right)$ sedangkan dalam ASTM satuanya adalah (psi). Dua angka terakir dalam kedua sistem standar tersebut menunjukan jenis fluks dan posisi pengelasan. [Harsono Wiryosumarto,1996]
Tabel 1. Spesifikasi Elektroda Terbungkus. (AWS A5.1-64T) [Harsono Wiryosumarto,1996]

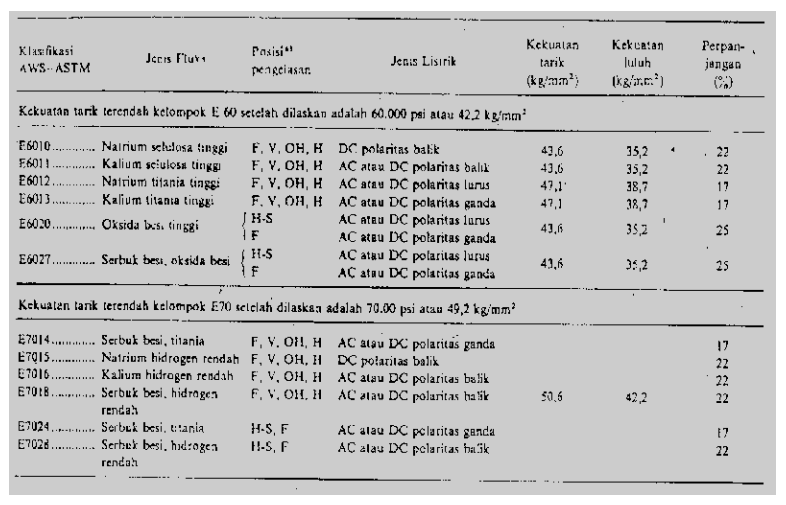

\section{Elektroda Penelitian}

\section{Elektroda A.}

Elektroda A diproduksi salah satu perusahaan Indonesia dengan klasifikasi AWS E6013 jenis fluks Kalium Titania tinggi berdiameter $3,2 \mathrm{~mm}$, kawat las ini untuk pengelasan baja ringan dengan kekuatan tarik tinggi. Posisi yang dianjurkan datar, vertikal, over head dan horizontal. Polaritas $A C$ dan $D C$ ganda.

\section{Elektroda B.}

Elektroda B diproduksi dari salah satu perusahaan Indonesia dengan klasifikasi AWS E6013 jenis fluks Kalium Titania tinggi berdiameter 3,2 mm, kawat las ini untuk pengelasan kontruksi umum bangunan, tangki dan lain-lain. Dengan kekuatan tarik tinggi, percikan las yang kecil, terak yang mudah lepas dan hasil pengelasan yang mulus. Posisi yang dianjurkan datar, vertikal, over head dan horizontal. Polaritas $A C$ dan $D C$ ganda.

\section{Elektroda C.}

Elektroda C dengan klasifikasi AWS E6013 jenis fluks Kalium Titania tinggi berdiameter $3,2 \mathrm{~mm}$, kawat las ini untuk pengelasan kontruksi secara umum, galangan kapal, kontruksi umum, kontruksi baja dan repair dan maintenance. Posisi yang dianjurkan datar, vertikal, over head dan horizontal. Polaritas $A C$ dan $D C$ ganda. 


\section{METODOLOGI}

Alur kerja penelitan adalah gambaran umum untuk memandu peneliti dalam melakukan penelitian. Alur kerja yang akan dilakukan adalah sebagai berikut :

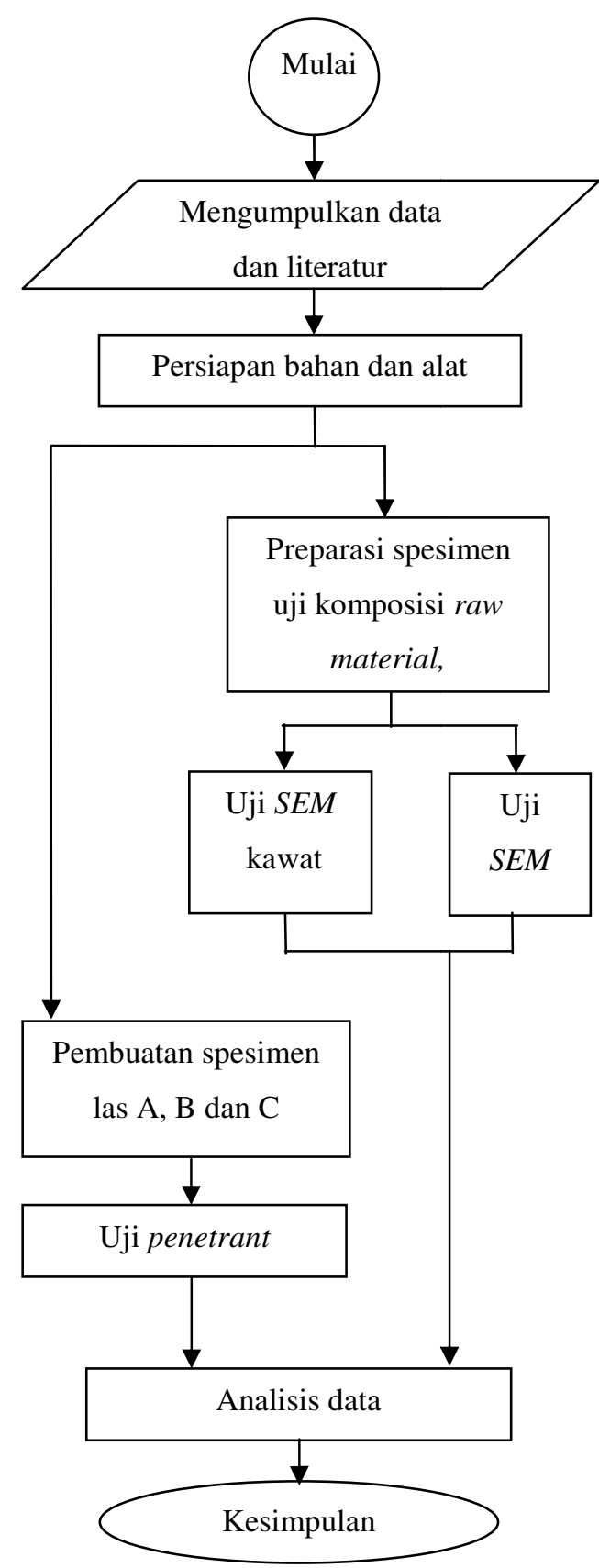

Gambar 2. Fowchart Penelitian

\section{HASIL dan PEMBAHASAN}

\section{A. Analisis Hasil Uji Komposisi Kawat Inti Elekroda}

Berdasarkan hasil uji komposisi kawat inti elektroda terdapat perbedaan persentase mass unsur yang terkandung dalam kawat inti elektroda A, B dan C.

Tabel 2. Perbandingan Mass Unsur pada Kawat Inti Elektroda

\begin{tabular}{|c|r|r|r|}
\hline \multirow{2}{*}{ Element } & \multicolumn{3}{|c|}{ Mass \% } \\
\cline { 2 - 4 } & \multicolumn{1}{|c|}{$\mathrm{A}$} & \multicolumn{1}{|c|}{$\mathrm{B}$} & \multicolumn{1}{c|}{$\mathrm{C}$} \\
\hline $\mathrm{C}$ & 23,69 & 16,21 & 32,00 \\
\hline $\mathrm{O}$ & 7,60 & 22,06 & 18,43 \\
\hline $\mathrm{Al}$ & - & - & 0,70 \\
\hline $\mathrm{Si}$ & 0,99 & 1,18 & 0,70 \\
\hline $\mathrm{Fe}$ & 67,72 & 60,55 & 48,13 \\
\hline Total & 100,00 & 100,00 & 100,00 \\
\hline
\end{tabular}

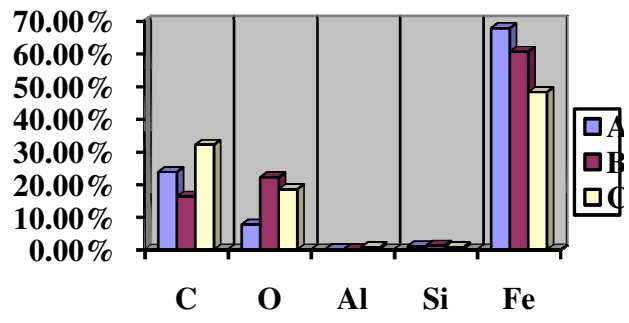

Gambar 3. Grafik Persentase Mass Unsur pada Kawat Inti Elektroda

Melihat tabel diatas dapat dilihat kawat inti elektroda A memiliki kandungan oksigen (O) paling sedikit yaitu $7,60 \%$ dibandingkan kawat inti elektroda B dan C. Kawat pengisi elektroda A juga memiliki kandungan besi $(\mathrm{Fe})$ lebih besar yaitu $67,72 \%$ dibandingkan kawat inti B dan $\mathrm{C}$.

Kawat inti elektroda B memiliki kandungan karbon (C) lebih sedikit sedikit yaitu 16,21\% dibandingkan kawat inti elektroda $\mathrm{A}$ dan $\mathrm{C}$. Kawat inti elektroda B juga memiliki kandungan oksigen (O) 22,06\% dan silikon ( $\mathrm{Si}$ ) 1,18\% lebih besar dibandingkan kawat inti elektroda A dan $\mathrm{C}$.

Kawat inti elektroda $\mathrm{C}$ yang memliki kandungan alumunium (Al), memiliki jumlah kandungan karbon (C) yang lebih banyak yaitu $32,00 \%$ dan memliki jumlah kandungan besi $(\mathrm{Fe})$ lebih sedikit yaitu $48,13 \%$ dibandingkan kawat inti elektroda A dan B . 
Dari data diatas maka dapat disimpulkan adanya perbedaan karakteristik komposisi unsur kawat inti elektroda dari ketiga sampel elektroda yang digunakan pada penelitian ini meski ketiga elektroda memiliki klasifikasi yang sama yaitu E6013.

\section{B. Analisis Hasil Uji Komposisi Fluks Elektroda}

Berdasarkan hasil uji komposisi fluks elektroda terdapat perbedaan persentase mass unsur yang terkandung dalam kawat pengisi elektroda A, B dan C.

Tabel 3. Perbandingan Mess Unsur pada Fluks Elektroda

\begin{tabular}{|c|r|r|r|}
\hline \multirow{2}{*}{ Element } & \multicolumn{3}{|c|}{ Mass \% } \\
\cline { 2 - 4 } & \multicolumn{1}{|c|}{$\mathrm{A}$} & \multicolumn{1}{|c|}{$\mathrm{B}$} & \multicolumn{1}{c|}{$\mathrm{C}$} \\
\hline $\mathrm{C}$ & 12,56 & 6,38 & 8,66 \\
\hline $\mathrm{O}$ & 57,86 & 19,09 & 17,16 \\
\hline $\mathrm{Na}$ & 13,30 & 5,97 & 1,64 \\
\hline $\mathrm{Mg}$ & - & 0,93 & - \\
\hline $\mathrm{Al}$ & 2,00 & 5,96 & 6,65 \\
\hline $\mathrm{Si}$ & 6,57 & 26,14 & 28,02 \\
\hline $\mathrm{K}$ & 1,58 & 12,02 & 7,61 \\
\hline $\mathrm{Ca}$ & 2,33 & 10,86 & 12,24 \\
\hline $\mathrm{Ti}$ & 2,15 & 7,80 & 8,52 \\
\hline $\mathrm{Mn}$ & 0,29 & 1,00 & 1,09 \\
\hline $\mathrm{Fe}$ & 1,37 & 3,85 & - \\
\hline $\mathrm{Total}$ & 100,00 & 100,00 & 100,00 \\
\hline
\end{tabular}

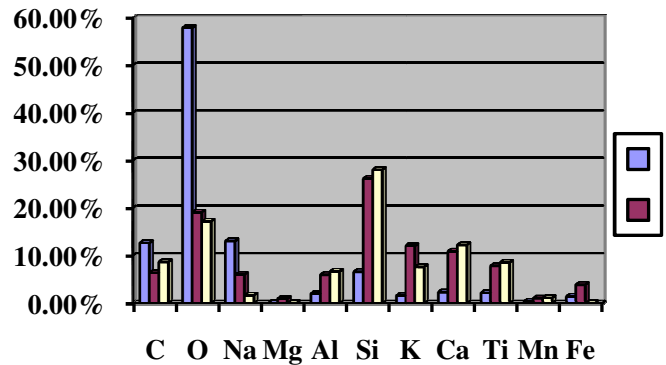

Gambar 4. Grafik Persentase Mass Unsur pada Fluks Elektroda

Melihat tabel diatas dapat dilihat fluks elektroda A memiliki kandungan karbon (C) 12,65\%, oksigen $(\mathrm{O}) \quad 57,86 \%$ dan natrium $(\mathrm{Na}) \quad 13,30 \%$ lebih banyak dibandingkan fluks elektroda sampel B dan C. Fluks elektroda A juga memiliki kandungan alumunium (Al) 2,00\%, silikon ( $\mathrm{Si}$ ) 6,57\%, kalium (K) 1,58\%, kalsium (Ca) 2,33\%, timah (Ti) 2,51\% dan mangan (Mn) 0,29\% lebih sedikit dibandingkan fulks elektroda B dan C.

Hanya fluks elektroda B yang memiliki kandungan magnesium (Mg) 0,93\%, fluks elektroda B juga memiliki kandungan karbon (C) lebih sedikit yaitu $6,38 \%$ dibandingkan fluks elektroda A dan C. Fluks elektroda B juga memiliki kandungan kalium (K) $12,02 \%$ dan besi (Fe) 3,85\% lebih banyak dibandingkan fluks elektroda A dan C.

Hanya fluks elektroda C yang tidak memliki kandungan mangan (Mg) dan besi (Fe), fluks elektroda $\mathrm{C}$ juga memiliki jumlah kandungan alumunium (Al) 6,65\%, silikon (Si) 28,02\%, kalsium (Ca) 12,24\%, calsium (Ca) 12,24\%, titanium (Ti) 8,52\%, dan mangan (Mn) 1,09\% lebih banyak dibandingkan fluks elektroda A dan B.

Dari data diatas maka dapat disimpulkan adanya perbedaan karakteristik komposisi unsur fluks elektroda dari ketiga elektroda yang digunakan pada penelitian ini meski ketiga elektroda memiliki klasifikasi yang sama yaitu E6013.

\section{Analisis Hasil Pengelasan Berdasarkan Hasil Uji Penetrant}

Uji penetrant dilakukan untuk mengetahui ada atau tidaknya cacat las pada hasil pengelasan. Sebagai berikut merupakan hasil uji penetrant.

1. Hasil uji penetrant pengelasan menggunakan elektroda A.

Berikut ini adalah hasil dari uji penetrant hasil pengelasan menggunakan elektroda A.

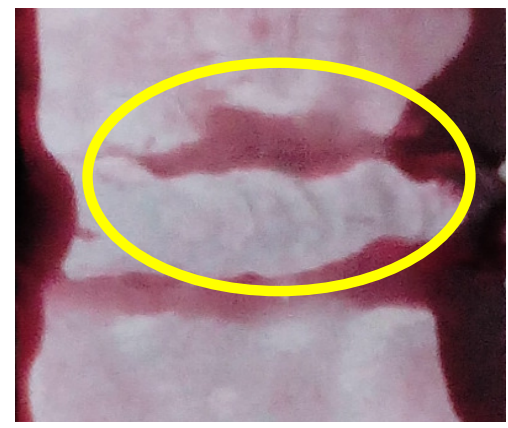

Gambar 5. Penetrant A.1.1

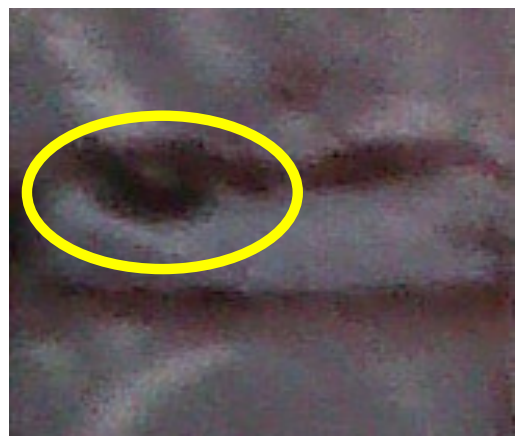

Gambar 6. Penetrant A.1.2 
Hasil uji penetrant A.1 pengelasan pada Gambar 5. Penetrant A.1.1 dan Gambar 6. Penetrant A.1.2 terlihat adanya cacat las jenis undercutting.

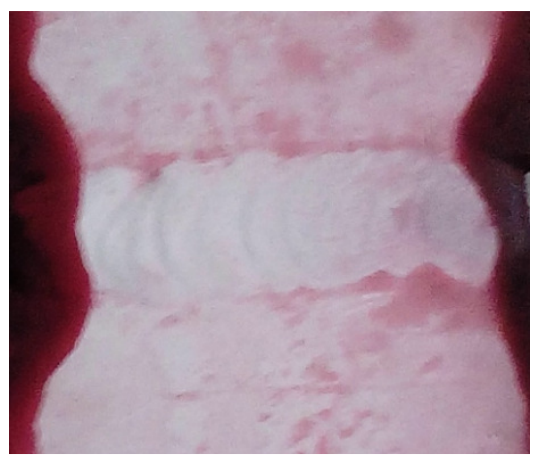

Gambar 7. Penetrant A.2.1

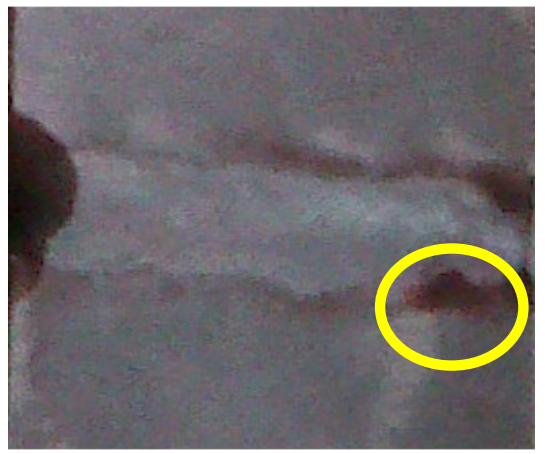

Gambar 8. Penetrant A.2.2

Hasil uji penetrant A.2 pengelasan pada Gambar 7. Penetrant A.2.1 tidak terlihat adanya cacat las sedangkan pada Gambar 8. Penetrant A.2.2 terlihat adanya cacat las jenis undercutting.

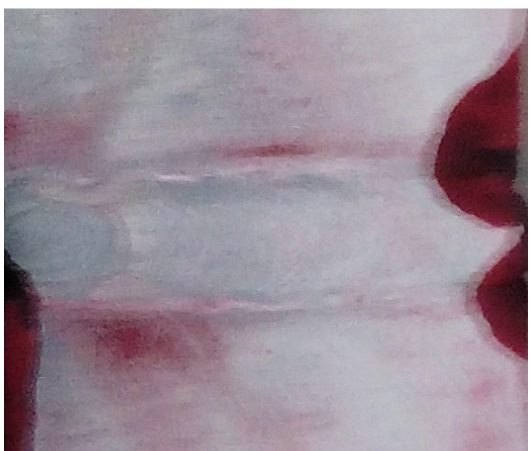

Gambar 9. Penetrant A.3.1

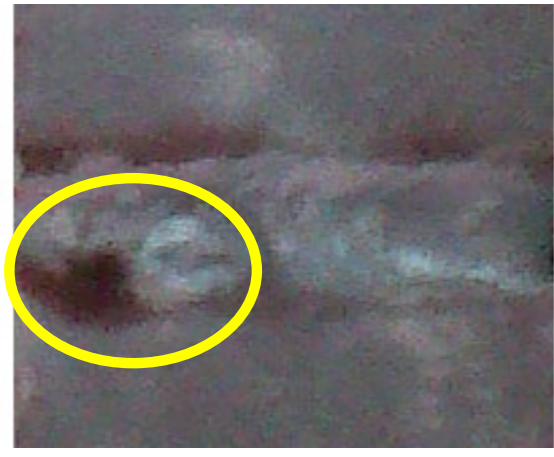

Gambar 10. Penetrant A.3.2

Hasil uji penetrant A.3 pengelasan pada Gambar 9. Penetrant A.3.1 tidak terlihat adanya cacat las sedangkan pada gambar 10. Penetrant A.3.2 terdapat cacat las fault of electrode change yang disebabkan adanya penggantian kawat las.

2. Hasil uji penetrant pengelasan menggunakan elektroda B.

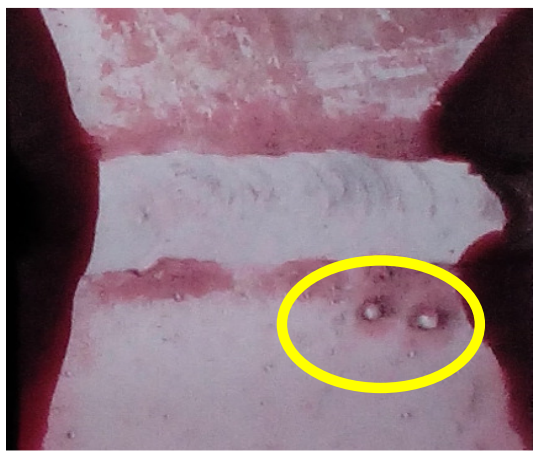

Gambar 11. Penetrant B.1.1

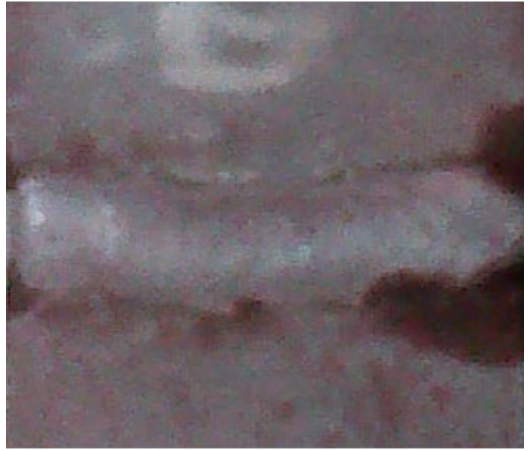

Gambar 12. Penetrant B.1.2

Hasil uji penetrant B.1 pengelasan pada Gambar 11. Penetrant B.1.1 terlihat adanya cacat las yang berjenis weld spatter sedangkan pada Gambar 12 . Penetrant B.1.2 tidak terlihat adanya cacat las. 


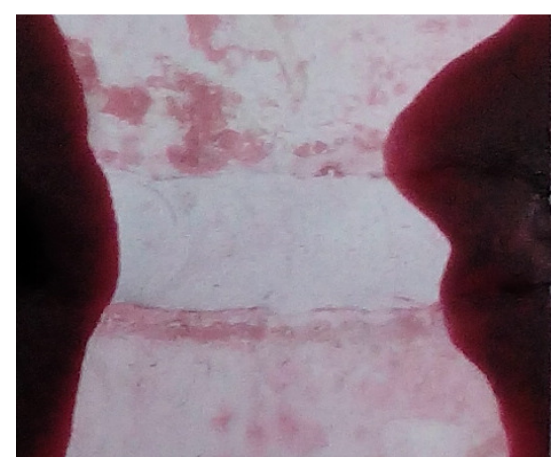

Gambar 13. Penetrant B.2.1

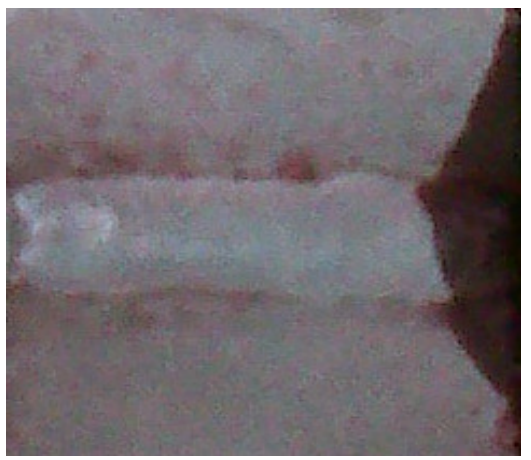

Gambar 14. Penetrant B.2.2

Hasil uji penetrant B.2 pengelasan pada Gambar 13. Penetrant B.2.1 dan pengelasan pada Gambar 14. Penetrant B.2.2 tidak terlihat adanya cacat las.

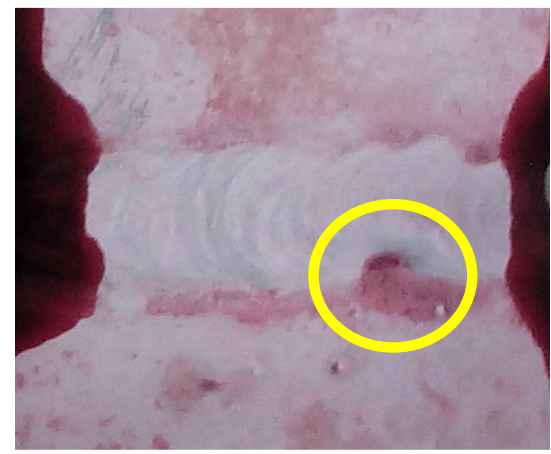

Gambar 15. Penetrant B.3.1

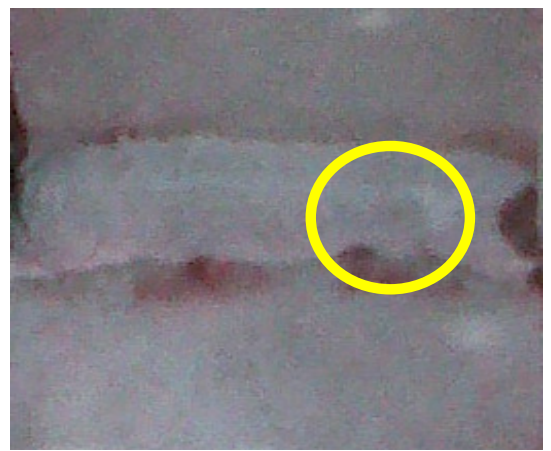

Gambar 16. Penetrant B.3.2
Hasil uji penetrant B.1 pengelasan pada Gambar 15. Penetrant B.3.1 dan Gambar 16. Penetrant B.3.2 terlihat adanya cacat las jenis undercutting.

3. Hasil uji penetrant pengelasan menggunakan elektroda $\mathrm{C}$.

Berikut ini adalah hasil dari uji visual pengelasan menggunakan elektroda $\mathrm{C}$.

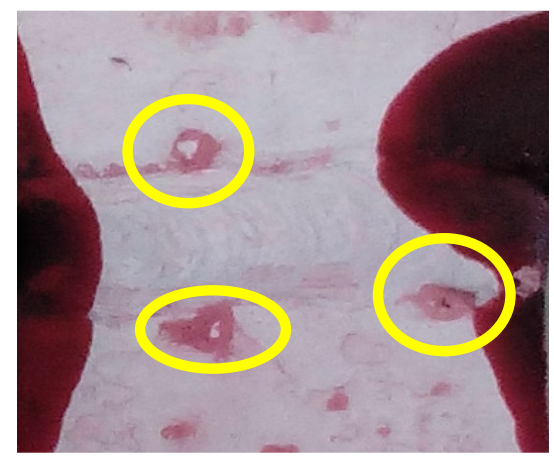

Gambar 17. Penetrant C.1.1

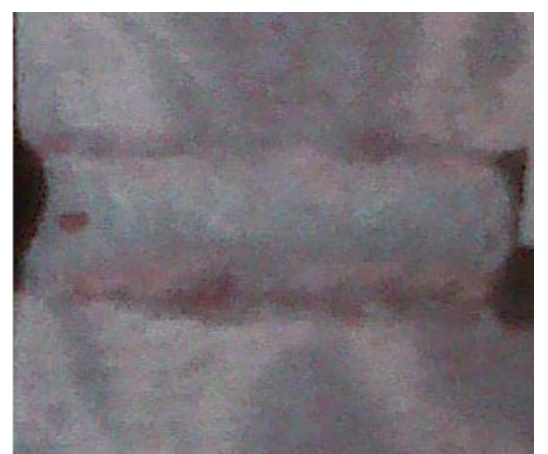

Gambar 18. Penetrant C.1.2

Hasil uji penetrant C. 1 pengelasan pada Gambar 17. Penetrant C.1.1 terlihat adanya cacat las yang berjenis weld sppatter sedangkan pada Gambar 18. Penetrant C.1.2 tidak terlihat adanya cacat las.

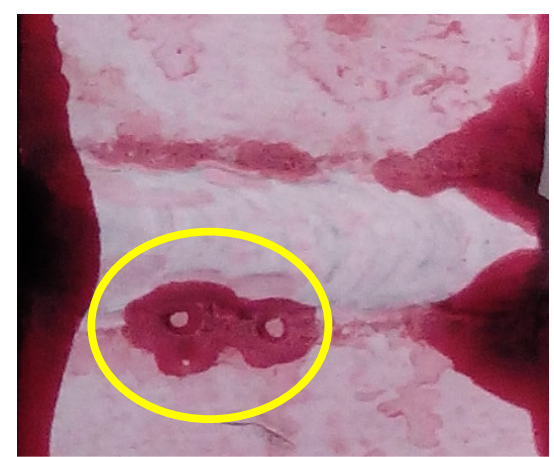

Gambar 19. Penetrant C.2.1 


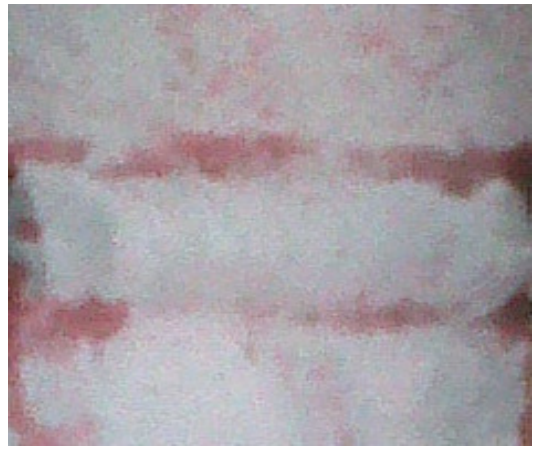

Gambar 20. Penetrant C.2.2

Hasil uji penetrant C.2 pengelasan pada Gambar 19. Penetrant C.2.1 terlihat adanya cacat las yang berjenis weld spatter sedangkan pada Gambar 20. Penetrant C.2.2 tidak terlihat adanya cacat las.

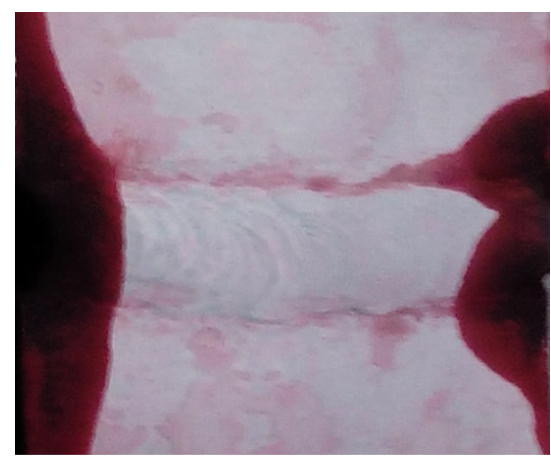

Gambar 21. Penetrant C.3.1

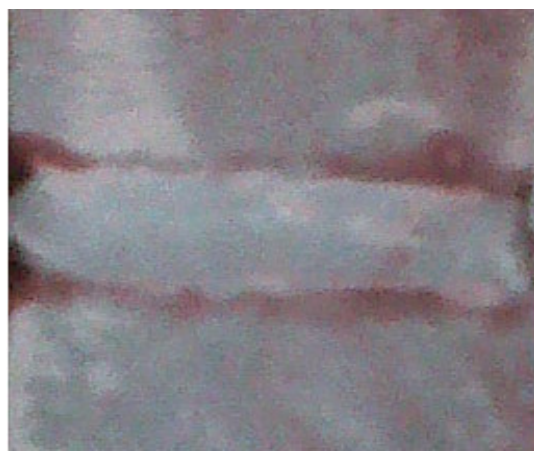

Gambar 22. Penetrant C.3.2

Hasil uji penetrant C.2 pengelasan pada Gambar 21. Penetrant C.2.1 dan pengelasan pada Gambar 22. Penetrant C.2.2 tidak terlihat adanya cacat las.

Berdasarkan hasil uji penetrant dapat dilihat adanya perbedaan cacat las yang terjadi pada tiap-tiap spesimen hasil pengelasan menggunakan ketiga elektroda. Berikut ini adalah tabel perbandingan cacat las berdasarkan hasil uji penetrant.

Tabel 4.Perbandingan Cacat Las Berdasarkan Hasil Uji Penetrant

\begin{tabular}{|c|c|c|c|}
\hline \multirow{2}{*}{$\begin{array}{l}\text { Kode } \\
\text { spesi } \\
\text { men }\end{array}$} & \multicolumn{3}{|c|}{ Cacat las } \\
\hline & A & $\mathrm{B}$ & $\mathrm{C}$ \\
\hline 1.1 & Undercutting & Undercutting & $\begin{array}{l}\text { Weld } \\
\text { spatter }\end{array}$ \\
\hline 1.2 & Undercutting & - & - \\
\hline 2.1 & - & - & $\begin{array}{c}\text { Weld } \\
\text { spatter }\end{array}$ \\
\hline 2.2 & - & - & - \\
\hline 3.1 & - & Undercutting & - \\
\hline 3.2 & $\begin{array}{c}\text { Fault of } \\
\text { electrode } \\
\text { change }\end{array}$ & Undercutting & - \\
\hline
\end{tabular}

Dari data diatas maka dapat disimpulkan hasil pengelasan menggunakan elektroda dengan $\mathrm{C}$ adalah yang terbaik dikarnakan sedikitnya cacat las yang terlihat dibandingkan hasil pengelasan menggunakan elektroda A dan B.

\section{KESIMPULAN}

Berikut ini adalah kesimpulan dari penelitian.

1. Karakteristik unsur fluks dari elektroda A, B dan C berbeda, walaupun menggunakan standar AWS A5.1 untuk klasifikasi E6013. Karakteristik unsur fluks dari elektroda A adalah karbon (C) 12,56\%, oksigen (O) $57,86 \%$, Natrium (Na) $13,30 \%$, alumunium (Al) $2,00 \%$, silikon (Si) 6,57\%, kalium (K) 1,58\%, kalsium (Ca) 2,33\%, titanium (Ti) 2,15\%, mangnesium (Mn) $0.29 \%$ dan besi (Fe) $1,37 \%$. Karakteristik unsur fluks dari elektroda B adalah karbon (C) 6,38\%, oksigen (O) 19,09\%, Natrium (Na) 5,97\%, magnesium $(\mathrm{Mg})$ 0,93\%, alumunium (Al) $5,96 \%$, silikon (Si) 26,14\%, kalium (K) $12,02 \%$, kalsium (Ca) 10,86\%, titanium (Ti) $7,80 \%$, mangnesium (Mn) 1,00\% dan besi (Fe) 3,85\%. Karakteristik unsur fluks dari elektroda C adalah karbon (C) 8,66\%, oksigen (O) $17,16 \%$, Natrium (Na) 1,64\%, alumunium (Al) 6,65\%, silikon (Si) 28,02\%, kalium (K) $7,61 \%$, kalsium (Ca) 12,24\%, titanium (Ti) $8,52 \%$, mangnesium (Mn) $1,09 \%$ dan besi (Fe) $1,37 \%$.

2. Karakteristik unsur kawat inti dari elektroda $\mathrm{A}, \mathrm{B}$ dan $\mathrm{C}$ berbeda, walaupun menggunakan standar AWS A5.1 untuk klasifikasi E6013. Karakteristik unsur kawat inti dari elektroda A adalah karbon (C) 23,69\%, oksigen (O) $7,60 \%$, silikon $(\mathrm{Si}) \quad 0,99 \%$ dan besi $(\mathrm{Fe})$ 
$67,72 \%$. Karakteristik unsur kawat inti dari elektroda B adalah karbon (C) $16,21 \%$, oksigen (O) $22,06 \%$, silikon ( $\mathrm{Si}$ ) $1,18 \%$ dan besi $(\mathrm{Fe}) 60,55 \%$. Karakteristik unsur kawat inti dari elektroda $\mathrm{C}$ adalah karbon (C) $32,00 \%$, oksigen $(\mathrm{O}) 18,43 \%$, alumunium $(\mathrm{Al})$ $0,70 \%$, silikon $(\mathrm{Si}) \quad 0,70 \%$ dan besi $(\mathrm{Fe})$ $48,13 \%$.

3. Cacat las yang terjadi berdasarkan hasil uji penetrant dari hasil pengelasan menggunakan elektroda sampel A adalah undercutting dan fault of electrode change, untuk hasil pengelasan menggunakan elektroda sampel B adalah undercutting dan hasil pengelasan menggunakan elektroda sampel $\mathrm{C}$ adalah weld spatter.

\section{DAFTAR PUSTAKA}

1. Alip, Mochamad. 1989. Teori dan Praktek Las. Jakarta: F.P.T.K. IKIP Yogyakarta.

2. Daryanto. 2010. Proses Besi dan Baja (Ilmu Metalurgi), Bandung: Sarana Tutorial Nurani Sejahtera.

3. Soenawan, Hery dan Suratman, Rochim. 2006. Pengantar Untuk Memahami Proses Pengelasan Logam, Bandung: Alfabeta.

4. Siswanto dan Amri, Saufan. 2011. Konsep Dasar Teknik Las, Jakarta: Prestasi Pustaka.

5. Widharto, Sri. 1987. Petunjuk Kerja Las, Jakarta: Pradnya Paramita.

6. Wiryosumarto, Harsono dan Okumura, Toshie. 1996. Teknologi Pengelasan Logam, Jakarta: Pradnya Paramita. 